Case report

\title{
SEASONAL CHANGES OF FREE-RADICAL INITIATED PROCESSES IN CYPRINIDS FROM THE MIDDLE VOLGA RIVER BASIN
}

\author{
N. A. PUDOVKIN ${ }^{1}$, V. V. SALAUTIN ${ }^{1}$, T. V. GARIPOV ${ }^{2}$, R. G. KARIMOVA ${ }^{2}$, \\ S. E. SALAUTINA ${ }^{1} \&$ P. V. SMUTNEV ${ }^{1}$ \\ ${ }^{1}$ Department of Animal Morphology, Pathology and Biology, Faculty of \\ Veterinary Medicine, Saratov State Agrarian University, Saratov, Russia; \\ ${ }^{2}$ Department of Physiology, Pathological Physiology, Faculty of Veterinary \\ Medicine, Kazan State Academy of Veterinary Medicine, Kazan, Russia
}

\begin{abstract}
Summary
Pudovkin, N. A., V. V. Salautin, T. V. Garipov, R. G. Karimova, S. E. Salautina \& P. V. Smutnev, 2018. Seasonal changes of free-radical initiated processes in cyprinids from the middle Volga river basin. Bulg. J. Vet. Med., 21, No 4, 478-482.

The purpose of this research was to study the free radical induced lipid oxidation in the commonest fish species inhabiting the Volga river, in the Middle Volga region of the Russian Federation, depending on the seasons of the year. The commonest fish species in the Volga river basin: European carp Cyprinus carpio (L., 1758), sabrefish Pelecus cultratus (L., 1758), common bream Abramis brama (L., 1758), tench Tinca tinca (L., 1758), and common roach Rutilus rutilus (L., 1758) were studied. The level of malondialdehyde and the activity of catalase were investigated in gills, liver, muscles and gonads. The values of molecular oxidative biomarkers in the studied fish species were significantly higher in the summer, suggestinga more active lipid peroxidation. The increase in catalase activity in the studied organs may indicate activation of the antioxidant defense system that can positively affect the growth and development of fish.
\end{abstract}

Key words: antioxidant system, carps, catalase, lipid peroxidation, malondialdehyde

All aspects of living organism's activity are influenced by a variety of biotic and non-biotic factors. One of the most important ecological factors is the ambient temperature. Temperature ranges beneficial for biological activity of a species are established by various adaptation mechanisms operating on different levels, i.e. post-transcriptional, molecular, biochemi- cal (metabolical) etc. (Orczewska et al., 2010; O’Brien, 2011; Somero, 2012; White et al., 2012).

One of these factors is free radical formation. Active forms of oxygen are usually created as metabolic byproducts. Environmental changes of processes can have a negative impact on pro-oxidation processes (Bhattacharjee, 2010). The in- 
fluence of temperature on lipid peroxidation (LP) processes for fish species inhabiting the Middle Volga river basin (Russian Federation) has not yet been studied completely. Therefore, the purpose of this study was to establish the seasonal patterns of free-radical initiated lipid oxidation for the most prominent fish species of the Middle Volga basin.

The studies were performed at the $\mathrm{N}$. I. Vavilov Saratov State Agrarian University in 2015 and 2016.

The 5 most abundant cyprinid species living in the Volga river basin were chosen as test subjects; the species included common carp Cyprinus carpio (L., 1758), sabrefish Pelecus cultratus (L., 1758), common bream Abramis brama (L., 1758), tench Tinea tinea (L., 1758) and roach Rutilus rutilus (L., 1758). Twelve fish of each species (two-year old males) or 60 fish in total were caught during the first month of each season of the year. The average weight of fish was as followed: $564.6 \pm 18.5 \mathrm{~g}$ for carps, $391.2 \pm 7.2 \mathrm{~g}$ for sabrefish; $166.0 \pm 10.2 \mathrm{~g}$ for bream; $209.2 \pm 10.2 \mathrm{~g}$ for tench and $377.6 \pm 6.6$ for roach. The fish were transferred to the laboratory at Saratov Agrarian University within three hours after their capture.

The concentration of malondialdehyde (MDA) was assayed by thiobarbituric acid test. It is based on a fact that free radical formation in polysaturated fatty acid molecules during LP processes is accompanied by formation of a system of conjugated double bonds leading to emergence of a new peak in absorption spectrum (Stalnaya \& Garyshvili, 1977). Antioxidant saturation of studied fish bodies was assessed by activity of catalase in blood serum and tissue homogenates. This method is based on the ability of hydrogen peroxide to form a stable coloured complex with molybdenum salts (Korotok,
1988). The validity of our research was verified by statistical methods using Microsoft Excel software. The sample difference was assessed by the t-test and differences presented with respect to winter data.

Studies of lipid peroxidation and antioxidant system activity of carps depending on the season established that maximum concentration of malondialdehyde (MDA) was observed during the summer period (Table 1).

According to our test results, MDA concentration in the tench gill tissue increased in the following order of seasons: winter $>$ spring $>$ autumn $>$ summer.

Fluctuations of MDA concentration in liver can be explained by endogenous fluctuations of lipid peroxidation level influenced by the length of daylight period. Liver as a central organ of fish metabolism is characterised by high intensity of exchange processes (including lipid exchange) and increased concentration of general lipids, nucleic acids, glycogen, proteins as well as all classes of structural and reserve lipids. Maximum lipid concentration is also connected to fish spawning period (Gostyukhina et al., 2010). All these characteristics of liver chemical composition and its specific functions are the most likely reason for increased LP activity in hepatic cells compared to cells of other fish organs.

The lowest MDA concentration for all studied fish species was observed in skeletal muscles. Such low LP product concentrations could be, most likely, attributed to lower concentration of lipids compared to other studied organs.

Thus, maximum concentration of malondialdehyde for most of studied fish species was observed during the summer while least concentrations - during the autumn and winter. Most intensive lipid 
Table 1. Concentration of malondialdehyde (nmol/g) in tissues of various species of carps during various seasons of the year

\begin{tabular}{|c|c|c|c|c|c|}
\hline Studied organs & Sabrefish & Bream & Carp & Tench & Roach \\
\hline \multicolumn{6}{|l|}{ Winter } \\
\hline $\begin{array}{l}\text { Gills } \\
\text { Liver } \\
\text { Muscles } \\
\text { Reproductive glands } \\
\end{array}$ & $\begin{array}{l}18.41 \pm 0.07 \\
16.42 \pm 0.33 \\
10.93 \pm 0.21 \\
11.01 \pm 0.17 \\
\end{array}$ & $\begin{array}{l}17.92 \pm 0.42 \\
17.05 \pm 0.42 \\
11.01 \pm 0.23 \\
14.44 \pm 0.33 \\
\end{array}$ & $\begin{array}{l}17.10 \pm 0.15 \\
21.03 \pm 0.85 \\
13.93 \pm 0.32 \\
11.79 \pm 0.43 \\
\end{array}$ & $\begin{array}{l}14.15 \pm 0.7 \\
18.87 \pm 0.56 \\
12.94 \pm 0.63 \\
11.42 \pm 0.27 \\
\end{array}$ & $\begin{array}{l}14.01 \pm 0.57 \\
18.82 \pm 0.32 \\
13.82 \pm 0.21 \\
13.57 \pm 0.18 \\
\end{array}$ \\
\hline \multicolumn{6}{|c|}{ Spring } \\
\hline $\begin{array}{l}\text { Gills } \\
\text { Liver } \\
\text { Muscles } \\
\text { Reproductive glands } \\
\end{array}$ & $\begin{array}{l}19.47 \pm 0.64 \\
18.34 \pm 0.19 * \\
12.47 \pm 0.33^{*} \\
12.99 \pm 0.50^{*} \\
\end{array}$ & $\begin{array}{l}19.17 \pm 0.33 \\
23.52 \pm 0.82 * \\
13.81 \pm 1.00^{*} \\
26.27 \pm 0.71 * \\
\end{array}$ & $\begin{array}{l}16.66 \pm 0.33 \\
19.86 \pm 0.25^{*} \\
12.40 \pm 0.74^{*} \\
10.03 \pm 0.03^{*} \\
\end{array}$ & $\begin{array}{l}17.41 \pm 0.24^{*} \\
19.36 \pm 0.19 \\
10.72 \pm 0.14^{*} \\
14.42 \pm 0.17^{*}\end{array}$ & $\begin{array}{l}17.05 \pm 0.84 * \\
20.01 \pm 0.47 * \\
13.55 \pm 0.33 \\
14.09 \pm 0.19 \\
\end{array}$ \\
\hline \multicolumn{6}{|l|}{ Summer } \\
\hline $\begin{array}{l}\text { Gills } \\
\text { Liver } \\
\text { Muscles } \\
\text { Reproductive glands } \\
\end{array}$ & $\begin{array}{l}26.99 \pm 1.23^{*} \\
29.65 \pm 1.42^{*} \\
21.76 \pm 0.93^{*} \\
25.56 \pm 1.21^{*} \\
\end{array}$ & $\begin{array}{l}28.41 \pm 1.03 * \\
27.33 \pm 1.70^{*} \\
23.00 \pm 1.82 * \\
27.87 \pm 1.33 * \\
\end{array}$ & $\begin{array}{l}28.69 \pm 1.11 * \\
28.12 \pm 1.73^{*} \\
21.98 \pm 0.96^{*} \\
26.36 \pm 1.03^{*} \\
\end{array}$ & $\begin{array}{l}27.12 \pm 1.33^{*} \\
29.81 \pm 2.01^{*} \\
22.65 \pm 0.91^{*} \\
27.03 \pm 1.49^{*}\end{array}$ & $\begin{array}{l}27.21 \pm 0.96^{*} \\
29.03 \pm 1.82 * \\
24.92 \pm 0.21 * \\
27.45 \pm 1.79 * \\
\end{array}$ \\
\hline \multicolumn{6}{|l|}{ Autumn } \\
\hline $\begin{array}{l}\text { Gills } \\
\text { Liver } \\
\text { Muscles } \\
\text { Reproductive glands }\end{array}$ & $\begin{array}{l}17.33 \pm 0.45 \\
19.64 \pm 0.32 * \\
15.87 \pm 0.88^{*} \\
18.56 \pm 0.87^{*}\end{array}$ & $\begin{array}{l}18.00 \pm 0.33 \\
19.45 \pm 1.03 * \\
16.33 \pm 0.81 * \\
17.93 \pm 0.33^{*}\end{array}$ & $\begin{array}{l}17.89 \pm 0.71 \\
18.67 \pm 0.95^{*} \\
16.70 \pm 0.66^{*} \\
16.67 \pm 0.80^{*}\end{array}$ & $\begin{array}{l}18.54 \pm 0.83^{*} \\
21.45 \pm 1.33^{*} \\
17.23 \pm 0.62^{*} \\
17.42 \pm 0.87^{*}\end{array}$ & $\begin{array}{l}18.35 \pm 0.69^{*} \\
20.32 \pm 0.53^{*} \\
17.23 \pm 0.72^{*} \\
18.00 \pm 1.12^{*}\end{array}$ \\
\hline
\end{tabular}

* $\mathrm{P} \leq 0.05$ compared to respective winter data.

peroxidation occurred in the liver, gills and reproductive glands.

We found out that catalase activity in bream gill tissues during the spring and the summer increased by 18.9 and $20 \%$, respectively, compared to the winter period (Table 2). High catalase activity in gills is an indicator of higher concentration of active forms of oxygen in this organ. It is also probably caused by breathing and oxygen exchange between external and internal environment performed by fish gills as their tissues are extensively vascularised. The primary free radical protection mechanism of gills is provided by red blood cell antioxidant system which also generates the majority of active forms of oxygen as a by-product of reaction between oxygen and haemoglobin. For example, the annual pattern of catalase activity for almost all of studied fish species (excluding sabrefish) increased in the following order: winter $>$ spring $>$ autumn $>$ summer.

The studies of catalase enzyme activity in tissues and organs established fluctuations of enzyme activity depending on the season of the year. The highest catalase enzyme activity was observed during the summer and the lowest - during the autumn and the winter.

Catalase enzyme activity level is also affected by seasonal fluctuations and depends on the state of LP. The highest enzyme activity was registered in gills and liver of studied carp species which can be 
Table 2. Catalase activity (U/L) in tissues of various cyprinid species during the different seasons of the year

\begin{tabular}{llllll}
\hline Studied organs & Sabrefish & Bream & Carp & Tench & Roach \\
\hline Winter & & & & & \\
Gills & $36.66 \pm 1.87$ & $41.67 \pm 2.15$ & $34.81 \pm 1.56$ & $39.50 \pm 1.98$ & $33.71 \pm 1.01$ \\
Liver & $41.98 \pm 2.12$ & $40.28 \pm 2.76$ & $42.41 \pm 0.93$ & $43.81 \pm 3.12$ & $32.18 \pm 0.40$ \\
Muscles & $29.32 \pm 2.01$ & $21.87 \pm 2.13$ & $33.50 \pm 1.04$ & $21.67 \pm 0.32$ & $24.99 \pm 1.60$ \\
Reproductive glands & $29.43 \pm 1.97$ & $34.73 \pm 2.01$ & $34.90 \pm 1.54$ & $33.76 \pm 1.33$ & $43.12 \pm 1.45$ \\
\hline Spring & & & & & \\
Gills & $47.53 \pm 0.67^{*}$ & $49.53 \pm 0.74^{*}$ & $42.72 \pm 0.87^{*}$ & $42.44 \pm 0.96^{*}$ & $34.43 \pm 0.97$ \\
Liver & $56.33 \pm 0.89^{*}$ & $45.99 \pm 0.83^{*}$ & $44.17 \pm 0.87$ & $46.15 \pm 1.30^{*}$ & $37.89 \pm 0.57^{*}$ \\
Muscles & $32.53 \pm 0.48^{*}$ & $29.15 \pm 0.73^{*}$ & $31.33 \pm 0.32$ & $25.32 \pm 1.15^{*}$ & $26.17 \pm 0.97$ \\
Reproductive glands & $37.15 \pm 0.49^{*}$ & $40.00 \pm 0.59^{*}$ & $35.42 \pm 0.27$ & $32.23 \pm 1.04$ & $43.13 \pm 1.10$ \\
\hline Summer & & & & & \\
Gills & $51.41 \pm 1.33^{*}$ & $50.01 \pm 1.00^{*}$ & $49.83 \pm 1.13^{*}$ & $49.92 \pm 0.17^{*}$ & $53.49 \pm 0.66^{*}$ \\
Liver & $60.01 \pm 1.25^{*}$ & $58.01 \pm 1.01^{*}$ & $55.36 \pm 1.33^{*}$ & $52.92 \pm 1.05^{*}$ & $59.98 \pm 1.03^{*}$ \\
Muscles & $35.72 \pm 0.93^{*}$ & $33.91 \pm 0.66^{*}$ & $39.74 \pm 0.81^{*}$ & $30.03 \pm 0.92^{*}$ & $29.86 \pm 1.52^{*}$ \\
Reproductive glands & $43.53 \pm 1.01^{*}$ & $45.95 \pm 0.72^{*}$ & $39.95 \pm 1.00^{*}$ & $39.59 \pm 0.69^{*}$ & $25.96 \pm 0.93^{*}$ \\
\hline Autumn & & & & & \\
Gills & $44.78 \pm 1.33^{*}$ & $42.11 \pm 1.78$ & $45.43 \pm 1.80^{*}$ & $44.33 \pm 2.48^{*}$ & $42.89 \pm 2.00^{*}$ \\
Liver & $54.33 \pm 2.01^{*}$ & $55.86 \pm 2.01^{*}$ & $52.54 \pm 2.23^{*}$ & $48.01 \pm 1.04^{*}$ & $51.09 \pm 2.72^{*}$ \\
Muscles & $29.67 \pm 1.45$ & $28.17 \pm 1.07^{*}$ & $25.76 \pm 1.05^{*}$ & $26.33 \pm 1.65^{*}$ & $27.56 \pm 1.09^{*}$ \\
Reproductive glands & $31.01 \pm 1.13$ & $29.03 \pm 1.21^{*}$ & $29.54 \pm 1.30^{*}$ & $28.87 \pm 1.54^{*}$ & $30.02 \pm 1.00^{*}$ \\
\hline
\end{tabular}

* $\mathrm{P} \leq 0.05$ compared to respective winter data.

explained by functional roles of these organs.

Thus, the values of molecular biomarkers of the oxidative system in the studied fish species in summer were significantly higher, indicating a more active process of lipid peroxidation. The results of our studies are consistent with the results of Person-Le Ruyet et al. (2004).

When studying the activity of catalase in tissues and organs, it was found that the activity of the enzyme fluctuated depending on the season of the year. The increase in catalase activity in the studied organs may point at activation of the antioxidant defense system that can positively affect the growth and development of fish. Our results are consistent with data published by Monteiro et al. (2007) and Ahmad et al. (2008).

In conclusion, to assess the status of fish and their habitats, seasonal variations of the studied oxidative biomarkers should be taken into account.

\section{ACKNOWLEDGEMENTS}

The authors would like to thank the Russian Foundation for Basic Research for the support of this study (project no. 16-34-00135 мол_a).

\section{REFERENCES}

Ahmad, I., V. L. Maria, M. Oliveira, A. Serafim, M. J. Bebianno, M. Pacheco \& M. A. Santos, 2008. DNA damage and lipid peroxidation vs. protection responses 
in the gill of Dicentrarchus labrax L. from a contaminated coastal lagoon (Ria de Aveiro, Portugal). The Science of the Total Environment, 406, 298-307.

Bhattacharjee, S., 2010. Sites of generation and physicochemical basis of formation of reactive oxygen species in plant cell. In: Reactive Oxygen Species and Antioxidants in Higher Plants, ed S. Dutta Gupta, Science Publishers, CRC Press, New York, pp. 1-30.

Gostyukhina, O. L., I. V. Golovina \& T. B. Vakhtina, 2010. Anti-oxidant complex of Psetta (Scophthalmus) maxima maeotica (L., 1758) as an indicator of fish physiological state. The Journal of Marine Eco$\log y$, 9, 15-22.

Korotok, M. A., 1988. Medical Biochemistry. Laboratory Science, 1, 40-41.

Monteiro M., C. Quintaneiro \& A. J. Nogueira, 2007. Impact of chemical exposure on the fish Pomatoschistus microps Kroyer (1838) in estuaries of the Portuguese Northwest coast. Chemosphere, 66, 514-522.

O'Brien, K. M., 2011. Mitochondrial biogenesis in cold bodied fishes. Journal of Experimental Biology, 214, 275-285.

Orczewska, J. I., G. Hartleben \& K. O’Brien, 2010. The molecular basis of aerobic metabolic remodeling differs between oxidative muscle and liver of three spine sticklebacks in response to cold acclimation. Journal Physiology. Regulatory, Integrative and Comparative Physiology, 299, 352-364.
Person-Le Ruyet, J., K. Mahe, N. Le Bayon \& H. Delliou, 2004. Effects of temperature on growth and metabolism in a Mediterranean population of European sea bass, Dicentrarchus labrax. Aquaculture, 237, 269-280.

Somero, G. N., 2012. The physiology of global change: Linking patterns to mechanisms. Annual Review of Marine Science, 4, 3961.

Stalnaya, I. D. \& T. G. Garyshvili, 1977. Malondialdehyde test method using thiobarbituric acid. In: Contemporary Biochemical Methods, ed. V.N. Orekhovich. Moscow, pp. 66-68 (RU).

White, C. R., L. A. Alton \& P. B. Frappell, 2012. Metabolic cold adaptation in fishes occurs at the level of whole animal, mitochondria and enzyme. Proceedings of the Royal Society B: Biological Sciences, 279, 1740-1747.

Paper received 12.10.2016; accepted for publication 06.02.2017

\section{Correspondence:}

Nikolay Pudovkin

Department of Animal Morphology,

Pathology and Biology,

Faculty of Veterinary Medicine,

N.I. Vavilov Saratov State Agrarian

Univeristy, Saratov, Russia

e-mail: niko-pudovkin@yandex.ru 